\title{
The "Down Syndrome Critical Region" Is Sufficient in the Mouse Model to Confer Behavioral, Neurophysiological, and Synaptic Phenotypes Characteristic of Down Syndrome
}

\author{
Nadia P. Belichenko, ${ }^{1}$ Pavel V. Belichenko, ${ }^{1}$ Alexander M. Kleschevnikov, ${ }^{1}$ Ahmad Salehi, ${ }^{1}$ Roger H. Reeves, ${ }^{2}$ \\ and William C. Mobley ${ }^{1}$ \\ ${ }^{1}$ Department of Neurology and Neurological Sciences and the Center for Research and Treatment of Down Syndrome, Stanford University Medical Center, \\ Stanford, California 94305-5489, and ${ }^{2}$ Department of Physiology and McKusick-Nathans Institute for Genetic Medicine, Johns Hopkins University School of \\ Medicine, Baltimore, Maryland 21025
}

\begin{abstract}
Down syndrome (DS) can be modeled in mice segmentally trisomic for mouse chromosome 16. Ts65Dn and Ts1Cje mouse models have been used to study DS neurobiological phenotypes including changes in cognitive ability, induction of long-term potentiation (LTP) in the fascia dentata (FD), the density and size of dendritic spines, and the structure of synapses. To explore the genetic basis for these phenotypes, we examined Ts1Rhr mice that are trisomic for a small subset of the genes triplicated in Ts65Dn and Ts1Cje mice. The 33 trisomic genes in Ts1Rhr represent a "DS critical region" that was once predicted to be sufficient to produce most DS phenotypes. We discovered significant alterations in an open field test, a novel object recognition test and in a T-maze task. As in Ts65Dn and Ts1Cje mice, LTP in FD of Ts1Rhr could be induced only after blocking $\mathrm{GABA}_{\mathrm{A}}$-dependent inhibitory neurotransmission. In addition, widespread enlargement of dendritic spines and decreased density of spines in FD were preserved in Ts1Rhr. Twenty of 48 phenotypes showed significant differences between Ts1Rhr and 2N controls. We conclude that important neurobiological phenotypes characteristic of DS are conserved in Ts1Rhr mice. The data support the view that biologically significant trisomic phenotypes occur because of dosage effects of genes in the Ts1Rhr trisomic segment and that increased dosage is sufficient to produce these changes. The stage is now set for studies to decipher the gene(s) that play a conspicuous role in creating these phenotypes.
\end{abstract}

\section{Introduction}

Down syndrome (DS), caused by trisomy for human chromosome 21 (HSA21), shows an incidence of $\sim 1$ in 733 live births (Canfield et al., 2006). DS is characterized by abnormalities in learning, memory, and language; some degree of mental retardation is essentially universal (Nelson et al., 2005). Changes in synaptic structure and function, especially in the hippocampus (Uecker and Obrzut, 1993; Brown et al., 2003; Pennington et al., 2003), appear to contribute substantially to cognitive dysfunction. Although DS pathogenesis may be complex, all changes must arise from excess genetic material on HSA21, which encodes $\sim 300$ known and predicted genes (Gardiner et al., 2003; Roizen and Patterson, 2003; Nikolaienko et al., 2005).

A frequently cited "Down syndrome critical region" (DSCR) extends $\sim 5.4 \mathrm{Mb}$ on HSA21q22. The critical region concept predicts that genes in a specific region are sufficient to produce DS

\footnotetext{
Received March 31, 2009; accepted April 3, 2009.

This work was supported by National Institutes of Health (Grants AG16999, NS38869, NS055371, NS24054, and HD38384), and grants from the L.L. Hillblom Foundation and the Down Syndrome Research and Treatment Foundation. We thank the members of the Mobley laboratory for critical reading of this manuscript and for many helpful discussions.

Correspondence should be addressed to Pavel V. Belichenko, Department of Neurology and Neurological Sciences, 1201 Welch Road, Room P220, Stanford University Medical Center, Stanford, CA 94305-5489. E-mail: pavel_belichenko@yahoo.com.

DOI:10.1523/JNEUROSCI.1547-09.2009

Copyright $\odot 2009$ Society for Neuroscience $\quad$ 0270-6474/09/295938-11\$15.00/0
}

phenotypes (Delabar et al., 1993; Korenberg et al., 1994). However, recent detailed study of segmental trisomy 21 in DS subjects argues against a single DSCR (Lyle et al., 2008). Of course, the point of these efforts is not to prove whether "critical regions" exist, but rather to understand which dosage-sensitive genes contribute to specific DS phenotypes. Given small numbers of subjects with partial trisomy 21 and a high degree of phenotypic variability even among those with full trisomy 21, this concept cannot be investigated rigorously in human beings. Conserved synteny between mouse chromosome 16 (MMU16) and HSA21 provides the basis for mouse genetic models of DS that create an opportunity to test the critical region concept. The Ts65Dn mouse, with an extra copy of $\sim 104$ mouse genes orthologous to those on HSA21, shows a number of developmental and functional parallels with DS. These include changes in behavior (Escorihuela et al., 1995, 1998; Reeves et al., 1995; Demas et al., 1996, 1998; Holtzman et al., 1996; Sago et al., 2000; Hyde and Crnic, 2001), alterations in the structure of dendritic spines in cortex and hippocampus (Belichenko et al., 2004), and failed long-term potentiation (LTP) in the hippocampus and fascia dentata (FD) (Siarey et al., 1997, 1999; Kleschevnikov et al., 2004). Ts1Cje mice, which are trisomic for a shorter but fully overlapping segment of MMU16 ( $~ 81$ genes), show similar changes, usually to a somewhat lesser degree (Sago et al., 1998, 2000; Siarey et al., 2005; Belichenko et al., 2007).

Ts1Rhr mice harbor an even smaller trisomic segment that 
corresponds closely to the DSCR defined by Delabar et al. (1993) and Korenberg et al. (1994) including 33 genes (herein, referred to as the "Ts1Rhr segment"). Contrary to predictions of the DSCR hypothesis, craniofacial dysmorphologies for Ts1Rhr are distinct from those in Ts65Dn and Ts1Cje mice (Olson et al., 2004). Furthermore, no differences were detected in the Morris water maze, induction of LTP in the CA1, hippocampal volume, or in cerebellum for Ts1Rhr mice inbred on C57BL/6J (B6.Ts1Rhr) (Olson et al., 2004, 2007; Aldridge et al., 2007). These results indicate that triplication of the Ts1Rhr segment is not sufficient to produce these correlates of DS phenotypes. Here, we identify important cognitive and synaptic neurobiological phenotypes in Ts1Rhr mice on the same genetic background in which they have been identified in Ts65Dn and Ts1Cje. In all, 20 of 48 phenotypes distinguished Ts1Rhr from their $2 \mathrm{~N}$ controls, many of which are also present in Ts65Dn mice. Thus, dosagesensitive genes in this region are sufficient to confer neurobiological phenotypes characteristic of DS.

\section{Materials and Methods}

All experiments were conducted in accordance with the National Institutes of Health guidelines for the care and use of animals and with an approved animal protocol from the Stanford University Institutional Animal Care and Use Committee. All efforts were made to minimize animal stress and discomfort.

\section{Mice}

$\mathrm{Dp}$ (16Cbr1-ORF9)1Rhr, referred to here as Ts1Rhr, were obtained from Reeves laboratory (Baltimore, MD). The Ts1Rhr mouse colony was maintained for $>7$ generations by crossing Ts1Rhr mice to $\mathrm{B}^{2} \mathrm{EiC}_{3} \mathrm{Sn} / \mathrm{J}$ F1 mice (The Jackson Laboratory). This breeding scheme is used to match the genetic background of Ts65Dn and Ts1Cje trisomic mice, which breed poorly or not at all on inbred backgrounds. To distinguish $2 \mathrm{~N}$ from Ts1Rhr mice, genomic DNA was extracted from tail clips and assessed by quantitative PCR protocol (provided by The Jackson Laboratory) to measure copies of $M x 1$ and $A p o B$ genes. $M x l$ is present in three and $A p o B$ is in two copies in Ts1Rhr. All mice were also typed for a recessive mutant allele of $P d e 6 b$, which causes retinal degeneration in homozygous mice. Only male mice that were wild type or heterozygous at this locus were used in all studies.

\section{Behavioral testing}

All mice were exposed to the same series of behavioral tests starting at 1.5-2 months of age. Each mouse was handled for $10 \mathrm{~min}$, twice a day, during the $7 \mathrm{~d}$ that preceded testing and for $3 \mathrm{~d}$ in between tests. The tests were administered in the following order: open field, object recognition task with $1 \mathrm{~h}$ delay, T-maze, locomotor activity, and object recognition with $24 \mathrm{~h}$ delay, with a minimum of $3 \mathrm{~d}$ between each test. All behavioral testing took place during the light cycle between 7:00 A.M. and 7:00 P.M. and was performed at room temperature $\left(22^{\circ} \mathrm{C}\right)$. On the day of testing, mice were in their home cages during the light phase in the same experimental room for $2 \mathrm{~h}$ for habituation. As a determiner of anxiety during each test, number of fecal pellets was also measured. To minimize olfactory cues from the previous trial, each apparatus was thoroughly cleaned with $10 \%$ ethanol after each animal. Handling and all behavioral tests were performed blindly to genotype by one investigator (N.P.B.).

Spontaneous locomotor activity test. Spontaneous locomotor activity was monitored using Plexiglas activity chambers (model MED-OFA-MS; Med Associates $)(27.9 \times 27.9 \times 20 \mathrm{~cm})$ and activity monitor software (Activity Monitor, version 4.3.6). Mice were placed into the center of the chamber under bright ambient light conditions and activity was monitored for $10 \mathrm{~min}$ in three separate trials. Average results were presented for total distance, velocity, total activity time, total activity counts and vertical activity.

Open field activity test. Open field activity was recorded with a video camera in a black Plexiglas chamber $(76 \times 76 \times 50 \mathrm{~cm})$ and analyzed with an automated videotracking system (Videotrack software, version 1.7 , Viewpoint Life Science). The speed for inactivity was set at $0-1 \mathrm{~cm} / \mathrm{s}$, for small activity at $1-5 \mathrm{~cm} / \mathrm{s}$, and for large activity at $>5 \mathrm{~cm} / \mathrm{s}$. Mice were placed into the same corner of chamber under dim ambient light conditions and activity was monitored for $10 \mathrm{~min}$ in a single trial. Results were averaged for total distance traveled, time spent and number of entries into the center of the field, around the periphery (the area extending 12 $\mathrm{cm}$ inside the sides of the field) or both.

Novel object recognition task. The Bevins and Besheer protocol (Bevins and Besheer, 2006) for two sample objects with one environment was used to study learning and memory with both 1 and $24 \mathrm{~h}$ delays in $2 \mathrm{~N}$ and Ts1Rhr mice. Before testing, mice were habituated in a black Plexiglas chamber $(31 \times 24 \times 20 \mathrm{~cm})$ during $10 \mathrm{~min}$ for 2 consecutive days under dim ambient light conditions. Activity of mice at age 3-4 months during the object recognition task was recorded with a video camera. First, two identical objects were placed in chamber as previously described (Bevins and Besheer, 2006). A mouse was placed at the mid-point of the wall opposite the sample objects. After $10 \mathrm{~min}$ exploring the objects, the mouse was return to the colony for $1 \mathrm{~h}$. To test for object recognition, one familiar object and one novel object were placed in the chamber and the mouse was again placed in the chamber for $3 \mathrm{~min}$ to explore the objects. Object recognition was measured in a single trial. Two weeks later the same test was repeated with $24 \mathrm{~h}$ delay. Results were averaged for total exploration time of two sample objects, novel and sample objects, and discrimination ratio (novel object interaction/total interaction with both objects).

T-maze testing. Mice at age 3-4 months were used. A modified Deacon and Rawlins protocol (Deacon and Rawlins, 2006) for a continuous alternation task in a T-maze was used to detect hippocampal function. The maze was made of opaque acrylic (Plexiglas) as described (Deacon and Rawlins, 2006) with an additional sliding door at the beginning of the start arm. During the test, a mouse was placed at the beginning of the start arm, with its back to the closed sliding door. After all doors were opened, the mouse ran down the start arm to choose either the right or left goal arm. After all four legs of the mouse had entered one goal arm, sliding door to another goal arm was closed for $5 \mathrm{~s}$, and then all sliding doors were opened again, allowing mice to go back to the start arm. T-maze activity was monitored until mice finished 10 alternations. This procedure was repeated for 3 consecutive days, for a total of 30 trials. The spontaneous alternation score was defined as the number of left-right and right-left alternations, expressed as a percentage of the total number of possible alternations during the session. Results were averaged for both alternation scores and time spent.

\section{Physiological recording from hippocampal slices}

The mice were 3-4 months of age. Physiological recordings were performed as described (Kleschevnikov et al., 2004). The mice were anesthetized with isoflurane before decapitation. The brain was quickly removed and immersed for 2-3 min in ice-cold artificial CSF (ACSF), containing (in mM): $119 \mathrm{NaCl}, 2.5 \mathrm{KCl}, 2.5 \mathrm{CaCl}_{2}, 1.3 \mathrm{MgSO}_{4}, 1 \mathrm{NaH}_{2} \mathrm{PO}_{4}, 26$ $\mathrm{NaHCO}_{3}$, and 10 glucose, osmolarity 310 , continuously bubbled with $95 \% \mathrm{O}_{2}$ and $5 \% \mathrm{CO}_{2}, \mathrm{pH}$ 7.4. The hippocampus was extracted and cut in ice-cold ACSF with a Vibratome (Leica 1000; Leica) into 350- $\mu$ m-thick transverse slices, which were allowed to recover in oxygenated ACSF at $32^{\circ} \mathrm{C}$ for $30 \mathrm{~min}$, then at room temperature for an additional $1-5 \mathrm{~h}$ before experimental recordings.

For recordings, a slice was transferred into the recording chamber and superfused with ACSF at a constant rate of $2.5 \mathrm{ml} / \mathrm{min}$ at a temperature of $32^{\circ} \mathrm{C}$. Recording electrodes were made of borosilicate glass capillaries (1B150F; World Precision Instruments) and filled with ACSF (resistance, 0.2-0.4 M $\Omega$ ); the stimulating monopolar electrodes were made of $\mathrm{Pt} / \mathrm{Ir}$ wire, diameter $25 \mu \mathrm{m}$ (WPI). Under visual control, the stimulating and recording electrodes were inserted into the middle molecular layer at a distance 300-350 $\mu \mathrm{m}$ apart from each other. Testing stimuli evoked field EPSPs (fEPSPs) that were $70-75 \%$ of maximum. The magnitude of the fEPSP was measured as the initial slope of the linear part of the fEPSP, which occurred 0.1-1 ms after the presynaptic volley. LTP was induced by tetanization with three trains of stimuli ( $1 \mathrm{~s}$ at $100 \mathrm{~Hz} ; 5$ min between the trains). In the experiments using $100 \mu \mathrm{M}$ picrotoxin, a single tetanization $(1 \mathrm{~s} ; 100 \mathrm{~Hz})$ was used. 


\section{Lucifer yellow microinjections, confocal microscopy and} image analysis

Lucifer yellow (LY) microinjections were performed on lightly fixed Vibratome slices, as described previously (Belichenko et al., 2004). In brief, $2 \mathrm{~N}$ and Ts1Rhr mice at age 6 months were anesthetized, perfused, and fixed. The brains were sectioned coronally at $200 \mu \mathrm{m}$ on a Vibratome and transferred to an injection chamber. Sections were floated onto a glass plate and held in place by a Millipore filter with a small window to allow for visualization of the tissue. The preparation was placed in a Petri dish and immersed in PBS, and this injection chamber was then transferred to a fluorescence microscope (Nikon Eclipse E800) equipped with a micromanipulator and a source of constant current (1.5 v battery, Duracell). Glass microelectrodes (outer diameter, $1.2 \mathrm{~mm}$; inner diameter, 0.94 $\mathrm{mm}$, Sutter Instrument) were filled with a $6 \%$ aqueous solution of LY CH dilithium salt (Sigma). After penetrating the cell body of a neuron with the microelectrode, LY was iontophoretically injected with a negative constant current of $2-5 \mathrm{nA}$ over $5 \mathrm{~min}$, during which time the label could be observed to fill the dendrites. Injected slices were mounted onto a glass slide and coverslipped with $90 \%$ glycerol in $0.1 \mathrm{~m}$ phosphate buffer, $\mathrm{pH}$ 7.4. Two slices per mouse were used: $40-50$ cells for the FD per mouse (with $n=3$, this results in a total of 120-150 cells); 20-30 motor cortex cells per mouse (with $n=3$ this results in a total of 60-90 cells) were analyzed. A specific domain for each dendrite type was examined: for FD, we examined each of the three subdivisions of the molecular layer in their entirety; for motor cortex basal and apical oblique, we examined dendrites immediately after the first bifurcation and then for $20-40 \mu \mathrm{m}$; and for motor cortex apical, we examined dendrites immediately after the appearance of first apical oblique dendrite.

Confocal microscopy was performed as described (Belichenko et al., 2004). Slices labeled with LY were examined and scanned in a Radiance 2000 confocal microscope (Bio-Rad) attached to a Nikon Eclipse E800 fluorescence microscope. The laser was an argon/krypton mixed gas laser with exciting wavelengths for LY (488 $\lambda$ ). LaserSharp software (Bio-Rad) was used to establish optimal conditions for collecting images. The morphology of LY-microinjected neurons and their spines was studied under the following optimal conditions: the lens was a $60 \times$ objective (Nikon; Plan Apo $60 \times / 1.40$ oil); laser power was $10 \%$, optical sections were scanned at increments of $0.5 \mu \mathrm{m}$; the zoom factor was 10 ; scanning was at 500 lines per second; each optical section was the result of three scans followed by Kalman filtering; pixel size was $0.039 \mu \mathrm{m}$; and the size of the image was $512 \times 512$ pixels. Each image was saved as a stack of individual optical sections and as a z-projection. LaserPix software analysis of the z-projection image of individual dendrites was used to measure the length and width of dendrites, count dendritic spines, measure the size of heads and the length of spine necks. The number of spines was calculated per $100 \mu \mathrm{m}$ length of dendrite. Digital images were imported, enhanced for brightness and contrast, assembled and labeled in Adobe Photoshop 7.0, and archived. Figures were printed with a HP Photosmart 1215 printer (Hewlett-Packard).

\section{Measuring body and brain weights, and regional brain volume, area and thickness}

$2 \mathrm{~N}$ and Ts1Rhr mice, at age 1.5 months, were handled each day for 10 min and weighed weekly before behavioral tests. After all behavioral tests, mice were deeply anesthetized with sodium pentobarbital $(200 \mathrm{mg} / \mathrm{kg}$ i.p.) (Abbott Laboratories), weighed again, and transcardially perfused for $1 \mathrm{~min}$ with $0.9 \%$ sodium chloride $(10 \mathrm{ml})$ and then for $10 \mathrm{~min}$ with $4 \%$ paraformaldehyde in $0.1 \mathrm{M} \mathrm{PBS}$, pH $7.4(100 \mathrm{ml})$. After perfusion, the brain was immediately removed. The weight of the brain (including the olfactory bulbs, cortex, hippocampus, cerebellum, brainstem and the cervical spinal cord through $\mathrm{C} 1-\mathrm{C} 2$ ) was recorded. The brain was then placed in fixative until further use. Seventy-micrometer-thick sections were cut, mounted and stained with cresyl violet, dehydrated, and coverslipped. Regional brain area or width measurements were performed on brain sections from mice at the age of 7.5 months, as described (Belichenko et al., 2004). The Image-Pro Plus program (Media Cybernetics) was used to outline each region in one hemisphere from each brain; the regions examined included the entire hippocampus, the molecular layer (ML) of FD, the granule cell layer (GCL), hilus and motor cortex. The area occupied by hippocampus, GCL, ML, hilus, the distances between lateral midline point of corpus callosum (CC) and three points of GCL (end of superior blade, crest and end of inferior blade), and thickness of motor cortex were measured using the Image-Pro Plus program and were exported to Excel. The volume of hippocampus was estimated by using the Cavalieri principle where the volume is equal to the sum of areas multiplied by the distance between the sections.

\section{Statistical analyses}

The data from behavioral testing, neurophysiology, dendritic morphology, body and brain weights, and brain anatomy were exported to Excel (Microsoft) and statistical comparisons were performed using two samples and two-tailed Student's $t$ test. All results are expressed as mean \pm SEM, and $p$ values $<0.05$ were considered to be significant.

\section{Results}

Ts1Rhr mice show cognitive and behavioral abnormalities

Among the most salient changes in people with DS and in mouse models are changes in behavior, including cognition. We performed several tests on $2 \mathrm{~N}$ and Ts1Rhr mice, including spontaneous locomotor activity test, open field test, object recognition tests and T-maze spontaneous alternation. The results are reported in Table 1 and Figures 1-4.

Female Ts65Dn mice have been reported to show increased locomotor activity during the dark cycle (Reeves et al., 1995). In a study performed in the dark but during the light phase, Ts65Dn mice were shown to be hyperactive, and Ts1Cje mice hypoactive, with respect to each other but not to their $2 \mathrm{~N}$ controls (Sago et al., 2000). Turner and colleagues detected no difference in spontaneous activity comparing Ts65Dn to $2 \mathrm{~N}$ mice (Turner et al., 2001). We tested Ts1Rhr and $2 \mathrm{~N}$ mice in a spontaneous locomotor activity test in the light and found no significant differences in total distance traveled or average velocity (Table 1, Fig. $1 a, b$ ). In addition, no significant differences were found in time spent or activity counts (Fig. $1 c, d$ ) or in the average number of fecal pellets eliminated ( $2 \mathrm{~N}: 3.9 \pm 0.4, n=15$; Ts1Rhr: $3.7 \pm 0.3, n=23$; $p=$ 0.7 ), a measure of anxiety, during this task. Whereas in an earlier report Ts65Dn mice showed no change in rearing during the light cycle (Reeves et al., 1995), Ts1Rhr mice spent significantly less time in vertical movement than did $2 \mathrm{~N}$ controls (Table 1, Fig. 1e). We conclude that under these conditions, Ts1Rhr mice, like Ts65Dn differ little if at all in spontaneous locomotion.

Next, we explored behavior in the novel open field activity test (Table 1; supplemental Table S2, available at www.jneurosci.org as supplemental material; Fig. 2). Again, there were no significant differences in $2 \mathrm{~N}$ versus Ts1Rhr in total distance traveled ( $p=$ 0.07). However, Ts1Rhr mice spent more time and traveled a longer distance in the periphery of the open field than $2 \mathrm{~N}$ mice $(p$ $=0.03$ ) (Table 1; supplemental Table S2, available at www .jneurosci.org as supplemental material; Fig. $2 a$ ). The difference was mainly observed during the middle of the $10 \mathrm{~min}$ period of testing, specifically during the third and fourth 2-min-block (Fig. $2 b$; supplemental Table S2, available at www.jneurosci.org as supplemental material). The average number of pellets produced during this task was similar $(2 \mathrm{~N}: 1.73 \pm 0.54, n=15$; Ts1Rhr: $1.74 \pm 0.47, n=23 ; p=0.99$ ). Thus, Ts1Rhr mice do differ significantly in open field activity and, especially for activity near the edge of the testing field-i.e., thigmotaxis.

To study learning and memory, we tested mice in the novel object recognition test with delays of 1 and $24 \mathrm{~h}$. One report notes deficits in novel object recognition for Ts65Dn mice (Fernandez et al., 2007) whereas another does not (Hyde and Crnic, 2002), but this discrepancy may relate to differences in the test paradigms in the two studies. We used a different and simple but well 
Table 1. Comparisons of severity of phenotypic features in $2 \mathrm{~N}$ versus Ts1Rhr mice

\begin{tabular}{|c|c|c|c|}
\hline Phenotype & $2 \mathrm{~N}$ & Ts1Rhr & $p$ value \\
\hline \multicolumn{4}{|l|}{ Behavior } \\
\hline \multicolumn{4}{|l|}{ Locomotor activity test } \\
\hline Total distance during $10 \mathrm{~min}(\mathrm{~m})$ & $18.4 \pm 1.2$ & $20.9 \pm 2.2$ & 0.38 \\
\hline Average velocity (cm/min) & $28.5 \pm 0.7$ & $28.3 \pm 0.6$ & 0.81 \\
\hline Average vertical time during $10 \mathrm{~min}(\mathrm{~s})$ & $125.1 \pm 6.1$ & $109.6 \pm 4.1$ & -0.03 \\
\hline Open field activity test & Normal & Thigmotaxic & -0.03 \\
\hline \multicolumn{4}{|l|}{ Novel object recognition test } \\
\hline Exploration time ( $1 \mathrm{~h}$ delay test) $(\mathrm{s})$ & $44.0 \pm 4.0$ & $35.6 \pm 2.5$ & -0.03 \\
\hline Discrimination ratio ( $1 \mathrm{~h}$ delay test) & $0.80 \pm 0.03$ & $0.79 \pm 0.03$ & 0.38 \\
\hline Exploration time ( $24 \mathrm{~h}$ delay test) (s) & $28.5 \pm 2.6$ & $23.3 \pm 1.8$ & 0.09 \\
\hline Discrimination ratio ( $24 \mathrm{~h}$ delay test) & $0.89 \pm 0.01$ & $0.83 \pm 0.02$ & -0.04 \\
\hline Continuous alternation task in T-maze (\%) & $57.4 \pm 1.8$ & $47.2 \pm 3.1$ & -0.02 \\
\hline \multicolumn{4}{|l|}{ Neurophysiology } \\
\hline LTP in control conditions (\%) & $113.2 \pm 3.0$ & $94.4 \pm 4.6$ & -0.01 \\
\hline LTP in picrotoxin (\%) & $142.3 \pm 12.1$ & $152.4 \pm 16.1$ & 0.62 \\
\hline \multicolumn{4}{|l|}{ Dendritic morphology } \\
\hline \multicolumn{4}{|l|}{ Fascia dentata: } \\
\hline Average spine density, total (per $100 \mu \mathrm{m}$ ) & $201.0 \pm 1.1$ & $172.2 \pm 1.5$ & $-<0.001$ \\
\hline Inner ML & $198.1 \pm 5.1$ & $168.2 \pm 6.9$ & -0.001 \\
\hline Middle ML & $204.0 \pm 4.7$ & $189.6 \pm 5.3$ & -0.04 \\
\hline Outer ML & $200.5 \pm 5.6$ & $162.3 \pm 5.4$ & $-<0.001$ \\
\hline Average width of dendrite, total ( $\mu \mathrm{m})$ & $0.89 \pm 0.01$ & $0.87 \pm 0.02$ & 0.95 \\
\hline Inner ML & $1.08 \pm 0.03$ & $1.11 \pm 0.04$ & 0.46 \\
\hline Middle ML & $0.87 \pm 0.02$ & $0.86 \pm 0.02$ & 0.76 \\
\hline Outer ML & $0.70 \pm 0.02$ & $0.67 \pm 0.02$ & 0.20 \\
\hline Area of spine head, $\mu \mathrm{m}^{2}$ & $0.161 \pm 0.003$ & $0.173 \pm 0.004$ & +0.01 \\
\hline Length of spine neck, $\mu \mathrm{m}$ & $0.34 \pm 0.01$ & $0.36 \pm 0.01$ & 0.25 \\
\hline \multicolumn{4}{|l|}{ Layers II-III pyramidal neurons in motor cortex: } \\
\hline Average spine density, layers II-III basal (per $100 \mu \mathrm{m}$ ) & $111.1 \pm 4.9$ & $122.9 \pm 4.7$ & 0.08 \\
\hline Layers II-III apical & $105.0 \pm 4.7$ & $106.7 \pm 3.5$ & 0.81 \\
\hline Layers II-III apical oblique & $94.9 \pm 3.4$ & $99.0 \pm 3.4$ & 0.52 \\
\hline Average width of dendrite, layers II-III basal, $\mu \mathrm{m}$ & $0.73 \pm 0.02$ & $0.76 \pm 0.02$ & 0.19 \\
\hline Layers II-III apical & $1.24 \pm 0.04$ & $1.18 \pm 0.04$ & 0.98 \\
\hline Layers II-III apical oblique & $0.80 \pm 0.02$ & $0.71 \pm 0.02$ & -0.001 \\
\hline Area of spine head $\left(\mu \mathrm{m}^{2}\right)$ & $0.23 \pm 0.01$ & $0.27 \pm 0.01$ & +0.001 \\
\hline Length of spine neck, $\mu \mathrm{m}$ & $0.75 \pm 0.03$ & $0.73 \pm 0.03$ & 0.77 \\
\hline Body weight (at 3.5 months old) (g) & $29.0 \pm 0.4$ & $30.9 \pm 0.4$ & +0.002 \\
\hline \multicolumn{4}{|l|}{ Brain anatomy } \\
\hline Brain weight (at 7.5 months old) (g) & $0.45 \pm 0.01$ & $0.48 \pm 0.01$ & +0.01 \\
\hline Volume of entire hippocampus $\left(\times 10^{9} \mu \mathrm{m}^{3}\right)$ & $7.10 \pm 0.44$ & $8.14 \pm 0.52$ & 0.56 \\
\hline Anterior part $\left(\times 10^{9} \mu \mathrm{m}^{3}\right)$ & $1.38 \pm 0.07$ & $1.43 \pm 0.13$ & 0.79 \\
\hline Middle part $\left(\times 10^{9} \mu \mathrm{m}^{3}\right)$ & $3.27 \pm 0.16$ & $2.96 \pm 0.23$ & 0.37 \\
\hline Posterior part $\left(\times 10^{9} \mu \mathrm{m}^{3}\right)$ & $2.45 \pm 0.99$ & $3.76 \pm 0.29$ & +0.01 \\
\hline Area of granule cell layer $\left(\times 10^{3} \mu \mathrm{m}^{2}\right)$ & $115 \pm 7$ & $98 \pm 5$ & -0.04 \\
\hline Area of entire FD molecular layer $\left(\times 10^{3} \mu \mathrm{m}^{2}\right)$ & $197 \pm 16$ & $201 \pm 8$ & 0.61 \\
\hline Anterior part of $\mathrm{ML}\left(\times 10^{3} \mu \mathrm{m}^{2}\right)$ & $161 \pm 7$ & $180 \pm 5$ & +0.03 \\
\hline Middle part of $\mathrm{ML}\left(\times 10^{3} \mu \mathrm{m}^{2}\right)$ & $192 \pm 10$ & $184 \pm 6$ & 0.84 \\
\hline Posterior part of $\mathrm{ML}\left(\times 10^{3} \mu \mathrm{m}^{2}\right)$ & $285 \pm 21$ & $277 \pm 14$ & 0.93 \\
\hline Area of entire hilus $\left(\times 10^{3} \mu \mathrm{m}^{2}\right)$ & $167 \pm 24$ & $188 \pm 16$ & 0.48 \\
\hline Anterior part $\left(\times 10^{3} \mu \mathrm{m}^{2}\right)$ & $181 \pm 21$ & $270 \pm 30$ & +0.04 \\
\hline Middle part $\left(\times 10^{3} \mu \mathrm{m}^{2}\right)$ & $138 \pm 20$ & $123 \pm 4$ & 0.39 \\
\hline Posterior part $\left(\times 10^{3} \mu \mathrm{m}^{2}\right)$ & $225 \pm 15$ & $167 \pm 17$ & 0.25 \\
\hline Distance $C(-\mathrm{GCL}$ superior blade $(\mu \mathrm{m})$ & $2257 \pm 154$ & $2217 \pm 93$ & 0.82 \\
\hline Distance $C(-\mathrm{GCL}$ crest $(\mu \mathrm{m})$ & $1112 \pm 84$ & $1177 \pm 71$ & 0.58 \\
\hline Distance CC-GCL inferior blade $(\mu \mathrm{m})$ & $2067 \pm 138$ & $2042 \pm 79$ & 0.86 \\
\hline Thickness of motor cortex ( $\mu \mathrm{m})$ & $681 \pm 9$ & $750 \pm 14$ & +0.005 \\
\hline
\end{tabular}

All values are mean \pm SEM. + or - indicates increased or decreased values, respectively, of genotypic features relative to $2 \mathrm{~N}$. Bold represents significant difference of studied parameters. All phenotypes can be combined in the following domains: (1) locomotor activity, (2) open field activity, (3) novel object recognition, (4) T-maze alternation, (5) LTP, (6) dendritic morphology in fascia dentata, (7) dendritic morphology in motor cortex, (8) hippocampal anatomy, (9) motor cortex thickness, (10) brain weight, and (11) body weight. Note that all domains tested showed changes between $2 \mathrm{~N}$ and Ts1Rhr.

established paradigm to explore this aspect of cognitive function (Bevins and Besheer, 2006). Relative to $2 \mathrm{~N}$ mice, Ts1Rhr mice revealed lack of interest in 'novelty'. To begin, mice were placed in a cage with two novel objects. After a $1 \mathrm{~h}$ delay, mice were reintroduced into the box which now contained one new and one old object. The total exploration time for the new object was significantly greater than that for the old object for both genotypes (2N: $p<0.001$; Ts1Rhr: $p<0.001$ ) (Fig. $3 a$ ). There was no significant difference between $\mathrm{Ts} 1 \mathrm{Rhr}$ and $2 \mathrm{~N}$ mice; thus, there was no difference in the discrimination ratio (Fig. $3 c$ ). Using the 
same test sequence and objects 2 weeks later, we tested exploration of objects after a 24 h delay (Fig. $3 b$ ). There was a significantly reduced discrimination ratio between Ts1Rhr and $2 \mathrm{~N}$ mice $(p=0.04)$ (Fig. $3 c$; Table 1). The average number of pellets eliminated during this task was the same ( $2 \mathrm{~N}: 1.5 \pm 0.4, n=15$; Ts1Rhr: $1.5 \pm$ $0.6, n=23$; $p=0.88)$. To test for the interest that mice showed in novel objects, we examined total exploration time during this initial exposure. Whereas during the first test session it was significantly lower by $\sim 19 \%$ in Ts1Rhr mice ( $p=0.03$ ) (Fig. $3 a$; Table 1), in the second trial, no difference was apparent (Fig. 3b). We conclude that Ts1Rhr mice are significantly impaired in object recognition.

Next, we compared the performance of $2 \mathrm{~N}$ and Ts1Rhr mice in the T-maze spontaneous alternation task, a behavioral paradigm known to reveal dysfunction of the hippocampal system (Gerlai, 2001; Deacon and Rawlins, 2006) and to be abnormal in both Ts65Dn and Ts1Cje mice (Belichenko et al., 2007). T-maze performance of Ts1Rhr mice was significantly inferior to $2 \mathrm{~N}$ controls ( $p=0.02$ ) (Fig. $4 a$, Table 1). Importantly, the average time needed to finish 10 alternations was not significantly different in Ts1Rhr versus $2 \mathrm{~N}$ (Ts1Rhr: $8.2 \pm 0.4 \mathrm{~min}, n=23 ; 2 \mathrm{~N}: 8.6 \pm$ $0.5 \min , n=14 ; p=0.25$ ), nor was the average number of pellets during this task (Ts1Rhr: $0.8 \pm 0.3, n=23 ; 2 \mathrm{~N}: 1.0 \pm 0.4$, $n=14 ; p=0.30)$. Together, the findings point to abnormalities in cognitive function in Ts1Rhr mice, including changes in hippocampally mediated behaviors that are also affected in Ts65Dn and Ts1Cje mice.

\section{Failed induction of LTP in the Ts1Rhr fascia dentata}

Alterations in physiological properties in Ts65Dn and Ts1Cje mice (Kleschevnikov et al., 2004; Belichenko et al., 2007) constitute a robust phenotype that may be linked to changes in cognition. To test whether or not triplication of the Ts1Rhr segment was sufficient to reproduce these phenotypes, we examined them in Ts1Rhr mice. To examine synaptic plasticity, we evaluated LTP in hippocampal slices in FD. With the stimulating electrode placed in the middle molecular layer of FD, tetanization $(100 \mathrm{~Hz} ; 1 \mathrm{~s}$ train given three times, 5 min apart) in $2 \mathrm{~N}$ slices induced stable LTP $(113.2 \pm 3.0 \%$ of baseline; $n=6$; $p<0.01$ ) that lasted at least $1 \mathrm{~h}$ (Fig. $4 b$; Table 1 ). In contrast, the same tetanization protocol failed to induce LTP in slices from Ts1Rhr mice $(94.4 \pm 4.6 \% ; n=6 ; p=0.57$; Table 1$)$. The difference between $2 \mathrm{~N}$ and Ts1Rhr slices was apparent after the first tetanization train and persisted throughout the duration of the experiment. We previously found in Ts65Dn and Ts1Cje FD that LTP was not induced under control conditions, but was readily induced after suppression of $\mathrm{GABA}_{\mathrm{A}}$ receptors with picrotoxin.
To extend the comparison to Ts1Rhr mice, we attempted to induce LTP in the presence of picrotoxin $(100 \mu \mathrm{M})$ (Fig. $4 c)$. Under these conditions, tetanization $(1 \mathrm{~s}, 100 \mathrm{~Hz})$ successfully resulted in LTP in FD in both $2 \mathrm{~N}$ and Ts1Rhr slices $(p=0.62)$ (Fig. $4 c$; Table 1). The time and magnitude of the post-tetanic enhancement of the responses were identical ( $p>0.7$ for the amount of LTP measured at 50-60 min after tetanization). Thus, similar to Ts65Dn and Ts1Cje mice (Kleschevnikov et al., 2004; Belichenko et al., 2007), changes in synaptic plasticity that could be significantly reversed with picrotoxin also characterized the Ts1Rhr FD.

Changes in spine density and morphology in Ts1Rhr mice Marked changes in the density and morphology of dendritic spines are present in Ts65Dn and Ts1Cje mice (Belichenko et al., 2004, 2007, 2009), especially in hippocampus. To determine 
a

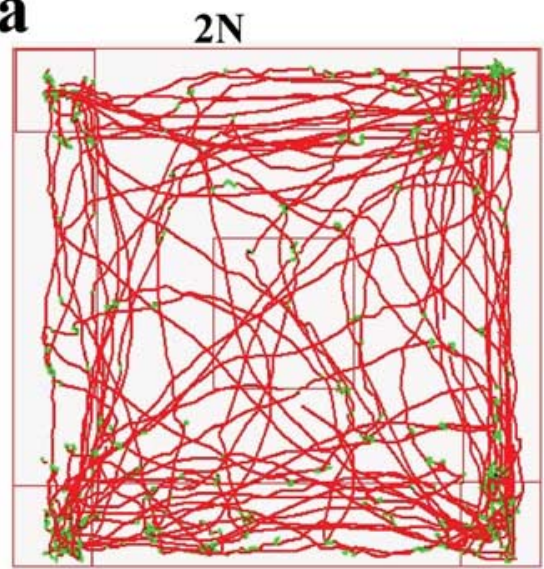

b

b
\begin{tabular}{|c|c|c|c|c|c|c|c|c|c|c|c|c|c|c|c|}
\hline $\begin{array}{c}\text { 2-min- } \\
\text { blocks }\end{array}$ & 1 & 2 & $\mathbf{3}$ & $\mathbf{4}$ & $\mathbf{5}$ & $\mathbf{1}$ & $\mathbf{2}$ & $\mathbf{3}$ & $\mathbf{4}$ & $\mathbf{5}$ & $\mathbf{1}$ & $\mathbf{2}$ & $\mathbf{3}$ & $\mathbf{4}$ & $\mathbf{5}$ \\
\hline $\begin{array}{c}\text { Inactivity } \\
\text { count }\end{array}$ & & & $\downarrow$ & $\downarrow$ & & & & & & & & & & $\downarrow$ & \\
\hline $\begin{array}{c}\text { Inactivity } \\
\text { duration }\end{array}$ & & & & $\downarrow$ & & & $\downarrow$ & & & & & & & $\downarrow$ & \\
\hline $\begin{array}{c}\text { Inactivity } \\
\text { distance }\end{array}$ & & & $\downarrow$ & $\downarrow$ & & & $\downarrow$ & & & & & & & $\downarrow$ & \\
\hline Small count & & & & & & $\downarrow$ & & & & & & & & & \\
\hline $\begin{array}{c}\text { Small } \\
\text { duration }\end{array}$ & & & & $\downarrow$ & & $\downarrow$ & & & $\downarrow$ & & & & & & \\
\hline $\begin{array}{c}\text { Small } \\
\text { distance }\end{array}$ & & & & & & $\downarrow$ & & & $\downarrow$ & & & & & & \\
\hline Large count & & & $\uparrow$ & & & $\downarrow$ & & & & & & $\uparrow$ & $\uparrow$ & $\uparrow$ & \\
\hline $\begin{array}{c}\text { Large } \\
\text { duration }\end{array}$ & & & $\uparrow$ & & & & & & & & & & $\uparrow$ & $\uparrow$ & \\
\hline $\begin{array}{c}\text { Large } \\
\text { distance }\end{array}$ & & & $\uparrow$ & $\uparrow$ & & & & & & & & & $\uparrow$ & $\uparrow$ & \\
\hline
\end{tabular}

Figure 2. Novel open field activity test. $\boldsymbol{a}$, Representative activity tracers for $2 \mathrm{~N}$ and Ts1Rhr mice during $10 \mathrm{~min}$. $\boldsymbol{b}$, Quantitative analysis of novel open field activity test breaking by 2 min blocks. Blue arrows show significantly decreased values and red arrows, significantly increased values for Ts1Rhr versus 2N. Note that Ts1Rhr mice spend more time and distance on average in the periphery of the field than $2 \mathrm{~N}$ mice.

whether the Ts1Rhr segment was sufficient to recreate these changes, we examined the structure of dendrites in FD and motor cortex (layers II-III). LY was microinjected into the cell bodies of individual neurons in brain slices from $2 \mathrm{~N}$ and Ts1Rhr to elucidate the morphology of dendrites and dendritic spines. Quantitative analysis was undertaken using confocal microscopy. The number of spines per $100 \mu \mathrm{m}$ length of dendrite was counted, and the width of individual dendrites was measured in z-projections of LY-microinjected neurons. We noted a statistically significant, $14 \%$ decrease of spine density in the FD of Ts1Rhr mice (Table 1, Fig. 5a). Decreases were present throughout the molecular layer and the change was significant for all three portions (inner, middle, and outer) (Table 1). The frequency distribution of spine density in FD gives evidence for an overall shift to lower values (Fig. 5b). No significant differences were recorded for spine density in the basal, apical or apical oblique dendrite of pyramidal neurons of layers II-III of motor cortex (Table 1).

With the exception of a difference in the width of apical dendrites in layers II-III of motor cortex, no differences in dendrite width were detected in Ts1Rhr. This measure thus largely mirrored the findings in Ts65Dn and Ts1Cje mice. Ts1Rhr mice showed a significant increase in the area of spine heads in all regions examined (Table 1; Fig. 5a), as shown previously in Ts65Dn and Ts1Cje mice (Belichenko et al., 2004, 2007). The frequency diagram of spine size points to the presence of some markedly enlarged spines in FD (Fig. $5 a, c$ ). In evaluating Ts65Dn and Ts1Cje mice, enlarged spines were defined as those with heads whose area was bigger than $0.5 \mu \mathrm{m}^{2}$ (Belichenko et al., 2004). In the present study, spines in FD larger than $0.5 \mu \mathrm{m}^{2}$ represented $\sim 4.6$ times the $2 \mathrm{~N}$ value $(0.7 \%$ of total in $2 \mathrm{~N}$ vs $3.2 \%$ in Ts1Rhr) in FD and $\sim 1.4$ times (6.6\% vs $9.4 \%$ ) in motor cortex. In Ts65Dn FD there were 10 times as many enlarged spines and in Ts1Cje they were 3 times more frequent (Belichenko et al., 2004, 2007). In contrast to Ts65Dn and Ts1Cje mice, Ts1Rhr did not show a change in the length of spine necks in FD and motor cortex (Table 1; Fig. 5d). The presence of selective changes in FD in spine density and the area of spine heads in Ts1Rhr mice demonstrates that some, but not all, spine phenotypes that characterize Ts65Dn and Ts1Cje mice are present in Ts1Rhr, and that the aggregate severity of the phenotypes is Ts65Dn $>$ Ts1Cje $>$ Ts1Rhr.

\section{Changes in body weight, brain weight,} and morphology in Ts1Rhr mice

To examine more generally the effects of segmental trisomy in Ts1Rhr, we measured body and brain weights and examined overall brain structure (Table 1; supplemental Table S1, available at www. jneurosci.org as supplemental material). Body weight was slightly higher in Ts1Rhr mice, reaching significance at ages 3 and 3.5 months ( $p=0.002)$. Brain weight was significantly heavier in Ts1Rhr at age 7.5 months $(p=0.01)$ (Table 1). Within the brain, the volume of the entire hippocampus was greater by $15 \%$, but the change was not significant $(p=0.56)$ (Table 1$)$. Examining hippocampal volume in three rostral-caudal sections (i.e., anterior, middle, and posterior), the only significant change was for the posterior hippocampus, which was significantly larger in Ts1Rhr mice $(p=$ 0.01 ) (Table 1). To determine which region of hippocampus was larger, we examined the area of GCL, the area of FD molecular layer, the area of hilus, and the distances between lateral midline point of CC and three points of GCL (end of superior blade, crest and end of inferior blade) (Table 1). Changes in volume were detected in the anterior and posterior hippocampus, but no simple pattern of changes emerged (Table 1). Finally, we measured the thickness of motor cortex, which was significantly larger in Ts1Rhr mice $(p=0.04)$ (Table 1$)$. The changes reported here point to differences in brain morphology in the Ts1Rhr mice that are not reported in earlier studies on Ts65Dn mice.

\section{Discussion}

DS phenotypes arise initially from gene dosage effects of HSA21 genes or regulatory sequences (Pritchard and Kola, 1999; Reeves 


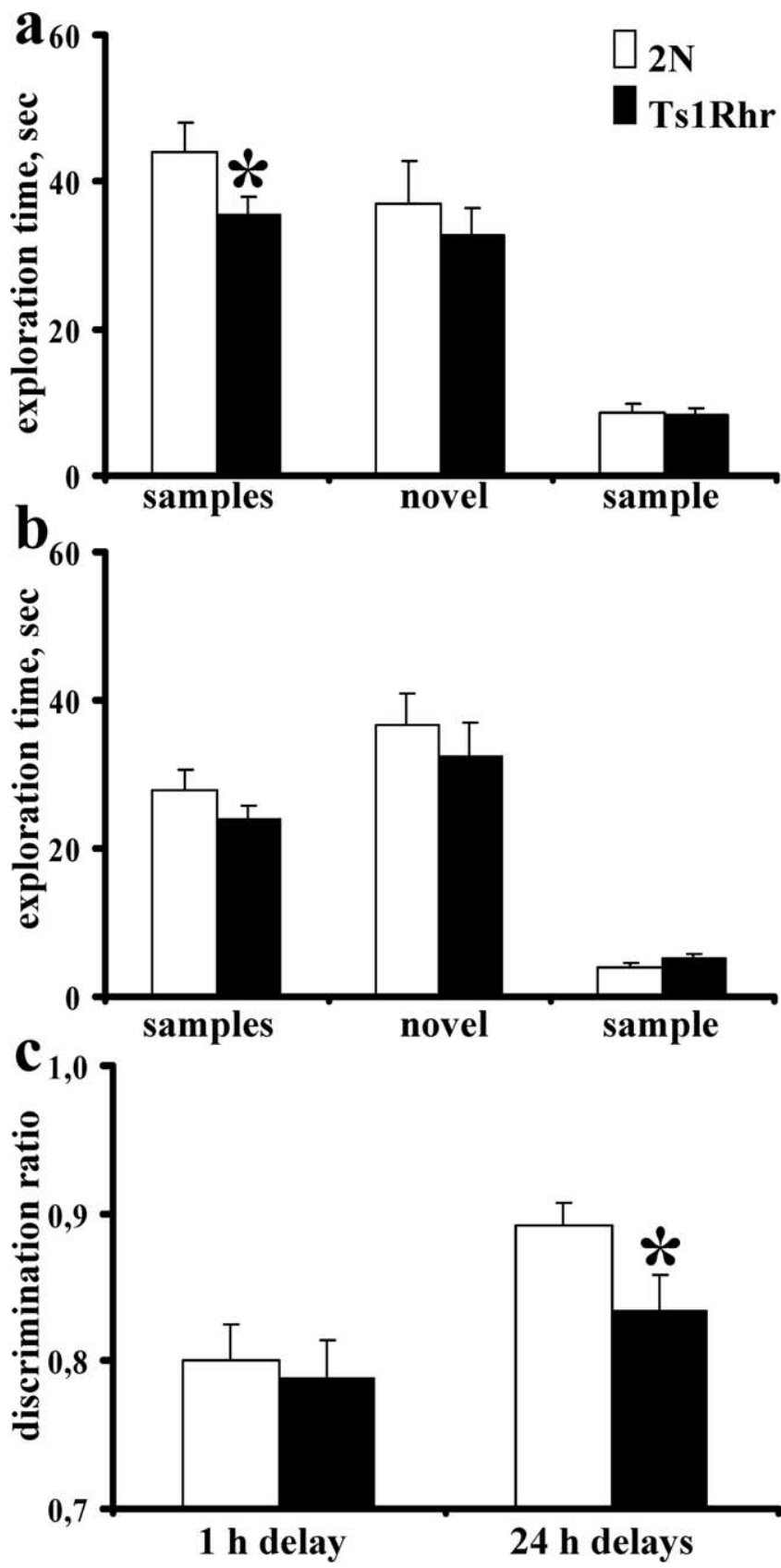

Figure 3. Novel object recognition test. $\boldsymbol{a}$, Exploration time for the first $10 \mathrm{~min}$ familiarization phase for two identical objects (samples) and for the $1 \mathrm{~h}$ delay second 3 min phase for novel (novel) and old (sample) objects presentation. $\boldsymbol{b}$, Exploration time as for $\boldsymbol{a}$ with $24 \mathrm{~h}$ delay. $\boldsymbol{c}$, Discrimination ratio for novel object recognition test with 1 and $24 \mathrm{~h}$ delays. Results are mean \pm SEM. Number of mice examined: $2 \mathrm{~N}=15$; Ts $1 \mathrm{Rhr}=23 .{ }^{*} p<0.05$, significantly different from $2 \mathrm{~N}$ mice.

et al., 2001; Roper and Reeves, 2006; Belichenko et al., 2007; Rachidi and Lopes, 2008). Studies in humans with segmental trisomy for HSA21 suggested that a region (the DSCR) at 21q22 harbored genes sufficient to produce many DS phenotypes, including cognitive dysfunction. Mouse models reflect aspects of impaired cognitive function in humans, and we examined phenotypes in mice with dosage imbalance for the 33 genes in the Ts1Rhr segment. The major findings of this study are that 20 of 48 phenotypes showed significant differences in specific behavioral, neurophysiological, and morphological phenotypes relevant to DS (Tables 1, 2). Indeed, it is possible to define 11 separate do-
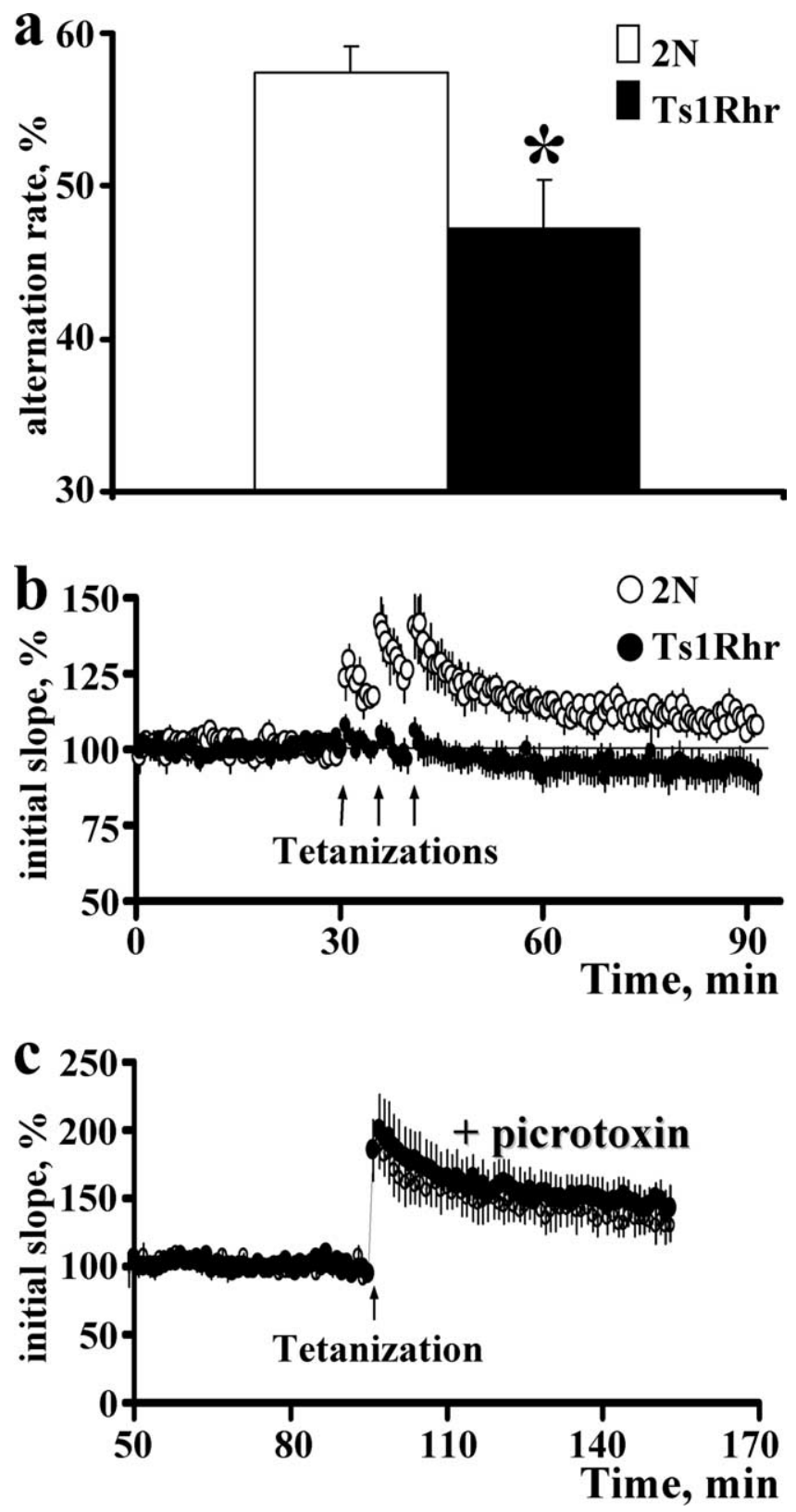

Figure 4. Hippocampal-dependent learning and synaptic plasticity in $2 \mathrm{~N}$ and Ts1Rhr mice. $\boldsymbol{a}$, Continuous alternation task in T-maze reveals dysfunction of the hippocampal system in Ts1 Rhr mice. Number of mice examined: $2 \mathrm{~N}=15 ; \mathrm{Ts} 1 \mathrm{Rhr}=23 . \boldsymbol{b}$, Induction of LTP was also deficient in Ts1Rhr fascia dentata. Time course of the averaged initial slope of the fEPSP. A series of three tetanizations (arrows) applied at 5 min intervals evoked stable LTP in 2N, but failed to induce LTP in the Ts1Rhr FD (open and filled circles, respectively). $c$, A single tetanization train (arrow) evoked stable LTP in both 2N and Ts1Rhr FD after suppressing inhibition with picrotoxin. The results are mean \pm SEM. The number of mice/slices examined: $2 \mathrm{~N}=6 / 6$; Ts $1 \mathrm{Rhr}=6 / 6$. ${ }^{*} p<0.05$, significantly different from $2 \mathrm{~N}$ mice.

mains in which changes were detected (see legend of Table 1). The degree of severity varied among different trisomic mouse models with more or fewer HSA21 orthologs triplicated. Previous studies showed that the Ts1Rhr segment genes are not required to produce some phenotypes observed in Ts65Dn mice, and necessary but not sufficient for other phenotypes (Olson et al., 2004, 2007; Aldridge et al., 2007). Here, we show that triplication of these 33 genes is sufficient to produce a number of structural and functional effects in the brain, including some not observed in either Ts65Dn or Ts1Cje mice. The data suggest that different 

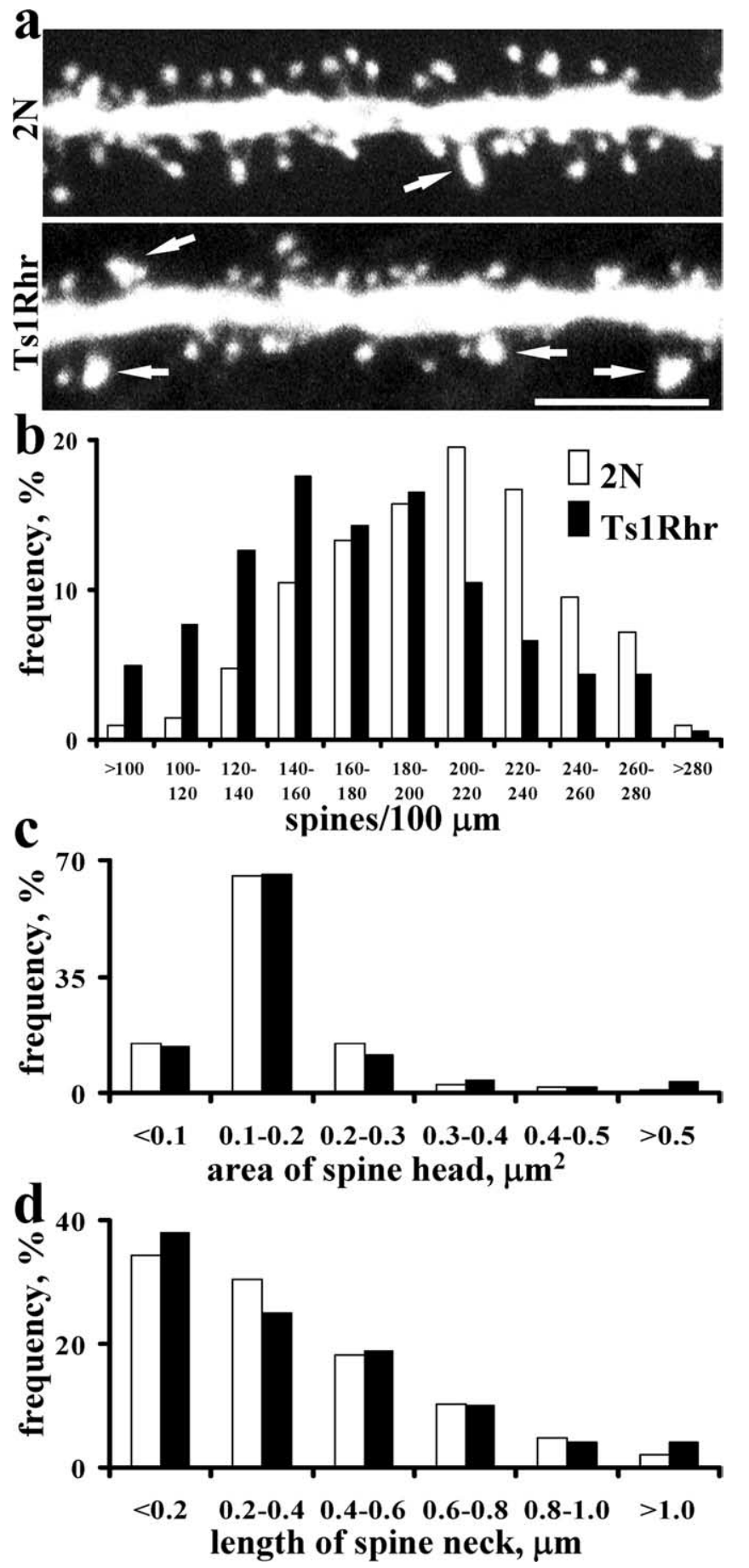

Figure 5. Spine morphology and analysis of the dendrites of granule cells of fascia dentata. $\boldsymbol{a}$, Confocal images of Lucifer yellow-microinjected dendrites and their spines in $2 \mathrm{~N}$ and Ts1Rhr mice. Note enlarged spines in Ts1Rhr mice (arrows) as well as a reduction in their number in fascia dentata. Scale bar, $5 \mu \mathrm{m} . \boldsymbol{b}-\boldsymbol{d}$, Quantitative analysis of the frequency distributions of spine densities ( $\boldsymbol{b})$, spine head areas ( $\boldsymbol{c}$ ), and spine neck lengths ( $\boldsymbol{d}$ ) in $2 \mathrm{~N}$ (open bars) and Ts1Rhr (solid bars) mice. Number of mice examined: $2 \mathrm{~N}=3$; Ts1Rhr $=3$.

phenotypes arise from different combinations of single or multiple gene dosage effects. The stage is now set for studies to decipher which genes are responsible for how increased dose leads to DS pathogenesis (Brault et al., 2006).

\section{Behavioral alterations in Ts1 Rhr}

Ts1Rhr mice differed from $2 \mathrm{~N}$ in an open field test, novel object recognition test and T-maze task. In the open field test, Ts1Rhr mice appeared to be more anxious but showed no difference in exploratory activity. Increased anxiety is among behavioral problems reported in children with DS. Changes in hippocampal function are characteristic of DS (Pennington et al., 2003) (for review, see Silverman, 2007). Two tests dependent on hippocampus were affected in Ts1Rhr mice. First, in the T-maze task of spontaneous alternation (Gerlai, 2001), we observed near-chance performance in Ts1Rhr mice compared with $2 \mathrm{~N}$, similar to previous findings in Ts65Dn and Ts1Cje (Granholm et al., 2002; Belichenko et al., 2007). Second, defects in novel object recognition have been found in Ts65Dn mice by some but not all investigators (Hyde and Crnic, 2002; Fernandez et al., 2007). Using a well established paradigm (Bevins and Besheer, 2006), we found marked changes in Ts1Rhr mice. Olson et al. (2007) showed that whereas Ts65Dn mice perform less well than $2 \mathrm{~N}$ mice in the Morris water maze, this was not the case for either Ts1Rhr or for Ts65Dn mice carrying the normal two copies (vs 3 copies) of the Ts1Rhr segment (i.e., Ms1Rhr/Ts65Dn mice). They concluded that Ts1Rhr segment genes may be necessary, but not sufficient, for this deficit in hippocampal function. The tasks used here are less stressful and more sensitive than the water maze, which may account for the differentiation of Ts1Rhr and $2 \mathrm{~N}$ in these hippocampal dependent tests. In any case, these findings demonstrate that triplication of genes in the Ts1Rhr segment is sufficient to affect hippocampal function, suggesting an analogous role in DS.

\section{Evidence of failed synaptic plasticity in the FD of Ts1Rhr,}

Ts1Cje, and Ts65Dn mice

Behavioral studies predicted that changes in synaptic plasticity would be seen in Ts1Rhr mice. Like Ts65Dn and Ts1Cje mice, there was a dramatic reduction in LTP in FD of Ts1Rhr mice, and the defect could be rescued by addition to slices of picrotoxin, an antagonist of $\mathrm{GABA}_{\mathrm{A}}$ receptors. The mechanism underlying failed LTP in the FD of Ts65Dn mice may represent an imbalance of excitatory and inhibitory neurotransmission with excessive inhibition (Kleschevnikov et al., 2004). The interpretation is consistent with picrotoxin rescue, but the physiological and genetic bases are yet to be defined. Interestingly, other changes suggestive of a selective increase in inhibitory neurotransmission have been documented recently for the FD (Belichenko et al., 2009). Whether such an imbalance is present more generally is uncertain. Using high-frequency tetanization, abnormal LTP has been reported in the CA1 region of the Ts65Dn hippocampus in some (Siarey et al., 1997, 1999) but not all studies (Costa and Grybko, 2005). However, Costa and Grybko (2005) were able to detect a defect in LTP using the theta burst protocol and found that it could be restored with picrotoxin. Using a protocol similar to ours in studies of LTP in B6.Ts1Rhr, no defect in LTP was discovered in CA1 (Olson et al., 2007). Studies to better define synaptic mechanisms will be needed to resolve this apparent discrepancy with our finding of an LTP deficit in FD of B6C3.Ts1Rhr mice.

\section{Conservation of changes in synaptic density and spine morphology in Ts1Rhr}

To determine whether electrophysiological changes are correlated with synaptic structure, we examined dendritic spines, the sites for synaptic contacts. Abnormalities in the density, shape and size of spines are documented in Ts65Dn and Ts1Cje mice, with the greatest changes in FD (Belichenko et al., 2004, 2007). Ts1Rhr mice recapitulated the decreased dendritic spine density and increased size of spine heads in FD. Notably, enlargement of spine heads was greatest in Ts65Dn mice (65\%), significantly less 
Table 2. Comparisons of severity of phenotypic features in trisomic mice

\begin{tabular}{|c|c|c|c|c|c|}
\hline Phenotype & Ts1Rhr/2N & $\mathrm{Ts1Cje} / 2 \mathrm{~N}^{a}$ & $\mathrm{Ts} 65 \mathrm{Dn} / 2 \mathrm{~N}^{a, b}$ & Ts1Rhr/Ts1Cje & Ts1Rhr/Ts65Dn \\
\hline \multicolumn{6}{|l|}{ Behavior } \\
\hline Alternation task in T-maze & $-(0.02)$ & $-(<0.01)$ & $-(<0.01)$ & n.s. & n.s. \\
\hline \multicolumn{6}{|l|}{ Neurophysiology } \\
\hline LTP in control conditions & $-(0.01)$ & $-(<0.01)$ & $-(<0.01)$ & n.s. & n.s. \\
\hline LTP in picrotoxin & n.s. & n.s. & n.s. & n.s. & n.s. \\
\hline \multicolumn{6}{|l|}{ Dendritic morphology } \\
\hline \multicolumn{6}{|l|}{ Fascia dentata: } \\
\hline Average spine density, total & $-14 \%$ & $-12 \%$ & $-18 \%$ & $-2 \%$ & $+4 \%$ \\
\hline Inner ML & $-15 \%$ & $-12 \%$ & $-18 \%$ & $-3 \%$ & $+3 \%$ \\
\hline Middle ML & $-7 \%$ & $-12 \%$ & $-23 \%$ & $+5 \%$ & $+16 \%$ \\
\hline Outer ML & $-19 \%$ & $-11 \%$ & $-13 \%$ & $-8 \%$ & $-6 \%$ \\
\hline Average width of dendrite, total & $-2 \%$ & $+4 \%$ & $+9 \%$ & $-6 \%$ & $-11 \%$ \\
\hline Inner ML & $+3 \%$ & $+6 \%$ & $+11 \%$ & $-3 \%$ & $-8 \%$ \\
\hline Middle ML & $-1 \%$ & $+4 \%$ & $+7 \%$ & $-5 \%$ & $-8 \%$ \\
\hline Outer ML & $-4 \%$ & $-2 \%$ & $+10 \%$ & $-2 \%$ & $-14 \%$ \\
\hline Area of spine head & $+7 \%$ & $+26 \%$ & $+65 \%$ & $-19 \%$ & $-58 \%$ \\
\hline Length of spine neck & $+6 \%$ & $-26 \%$ & $-34 \%$ & $+32 \%$ & $+40 \%$ \\
\hline \multicolumn{6}{|l|}{$\begin{array}{l}\text { Layers II-III pyramidal neurons in motor } \\
\text { cortex: }\end{array}$} \\
\hline Average spine density, layers II-III basal & $+11 \%$ & $-2 \%$ & $-15 \%$ & $+13 \%$ & $+26 \%$ \\
\hline Layers II-III apical & $+2 \%$ & $-6 \%$ & $-10 \%$ & $+8 \%$ & $+12 \%$ \\
\hline Layers II-III apical oblique & $+4 \%$ & $+13 \%$ & $-12 \%$ & $-9 \%$ & $-16 \%$ \\
\hline \multicolumn{6}{|l|}{ Average width of dendrite, layers II-III } \\
\hline basal & $+4 \%$ & $+6 \%$ & n.a. & $-2 \%$ & n.a. \\
\hline Layers II-III apical & $-5 \%$ & $+10 \%$ & n.a. & $-15 \%$ & n.a. \\
\hline Layers II-III apical oblique & $-11 \%$ & $+7 \%$ & n.a. & $-18 \%$ & n.a. \\
\hline Area of spine head & $+17 \%$ & $+17 \%$ & $+43 \%$ & $0 \%$ & $-26 \%$ \\
\hline Length of spine neck & $+3 \%$ & $-13 \%$ & $-15 \%$ & $+16 \%$ & $+18 \%$ \\
\hline Body weight & $+(<0.01)$ & $-(0.02)$ & $-(<0.01)$ & $-(0.02)$ & $+(<0.01)$ \\
\hline Brain weight & $+(0.01)$ & n.s. & n.s. & n.s. & n.s. \\
\hline
\end{tabular}

+ or - indicates increased or decreased values, respectively, of genotypic features relative to $2 \mathrm{~N}$ or between trisomic mice. $p$ values are shown in parenthesis. Bold represents significant difference of studied parameters. n.s., Not significant; n.a., data not available.

${ }^{a}$ Data are from Belichenko et al. (2007).

${ }^{b}$ Data are from Belichenko et al. (2004)

severe in Ts1Cje (26\%) and still less marked in Ts1Rhr mice (7\%) (Table 2). In contrast, the defect in spine density in the FD was similar across all genotypes: Ts65Dn (18\% decreased), Ts1Cje (12\%), and Ts1Rhr (14\%) (Table 2). Whereas spine necks were significantly shorter in Ts65Dn and Ts1Cje mice (34\% and 26\%), no difference was seen between Ts1Rhr and $2 \mathrm{~N}$. Heterogeneity in phenotypes with changes in spine density that were not necessarily correlated with dendrite width and vice versa, and may be impacted by the different pattern of afferent connections. Phenotypes with decreased severity suggest that genes present in Ts65Dn and Ts1Cje, but not Ts1Rhr, contribute. Nevertheless, the conservation of dendritic phenotypes in Ts1Rhr mice, most notably decreased spine density and enlarged spine heads, is evidence that genes present in the triplicated segment contribute to these abnormalities.

\section{Novel phenotypes in Ts1Rhr mice}

We entertained the possibility that the presence of the Ts1Rhr segment genes might produce changes in brain structure and function not seen in Ts65Dn or Ts1Cje mice. Examples of this were documented in studies comparing Ts1Cje and Ts65Dn mice (Olson et al., 2004, 2007; Belichenko et al., 2007). Indeed, we confirmed the occurrence of increased body and brain weight in Ts1Rhr relative to $2 \mathrm{~N}$ (Olson et al., 2004, 2007) and detected additional changes. Hippocampal volume was increased in specific subregions and motor cortex was significantly thicker in Ts1Rhr (Table 1). These findings suggest that people with partial trisomy 21 may demonstrate phenotypes not found in those with a full trisomy 21, an important consideration for analysis of this population.

\section{Exploring the genetic basis for neurobiological phenotypes}

To explicate the genes that cause phenotypes in Ts1Rhr, it is useful to consider candidate genes in the Ts1Rhr segment. This region extends from an inactivated copy of Cbrl through the mouse ortholog of C21orf11 and contains $\sim 33$ genes (Olson et al., 2004, 2007; Aldridge et al., 2007). Among the many genes in this region that must be considered as candidates, two, Dyrkla and Kcnj6 (Girk2), can readily be envisioned as affecting synapse formation and function. Dyrk1a is expressed at increased levels in Ts65Dn, Ts1Cje mice and Ts1Rhr mice (Saran et al., 2003; Amano et al., 2004; Ramakrishna et al., 2005). Increased expression of Dyrkla in transgenic mice results in a number of CNS phenotypes, including altered neuronal morphology and impairments in hippocampal-dependent learning tasks (Altafaj et al., 2001; Branchi et al., 2004; Ahn et al., 2006). However, differences in phenotypes documented in studies of Ts1Rhr compared with these transgenic mice suggest that increased dosage of Dyrkla alone is not sufficient to produce Ts1Rhr phenotypes. For example, Dyrkla transgenic mice have been reported to show increased locomotor activity (Altafaj et al., 2001; Branchi et al., 2004), whereas no such change was detected herein. Abnormalities in the Morris water maze were also reported in transgenic mice (Altafaj et al., 2001; Ahn et al., 2006) but not in Ts1Rhr mice (Olson et al., 2007). Finally, whereas Olson et al. (2007) reported 
no change in hippocampal LTP in Ts1Rhr, Ahn et al. (2006) reported increased LTP in Dyrkla transgenic mice.

Kcnj6 encodes Girk2, a subunit of a G protein-coupled inwardly rectifying potassium channel that serves as an effector for postsynaptic $\mathrm{GABA}_{\mathrm{B}}, 5 \mathrm{HT}-1 \mathrm{~A}$, muscarinic $\mathrm{m} 2$ and certain other receptors (Yamada et al., 1998; Mark and Herlitze, 2000). Kcnj6 is present in three copies in DS and in all the mouse models we have examined; Girk2 transcript levels are increased in Ts65Dn mice. Currents through the Girk2-containing channels drive resting membrane potential to the equilibrium potential of $\mathrm{K}^{+}$, thus increased expression may causes hyperpolarization of neuron as occurs in the FD of Ts65Dn mice (A. Kleschevnikov, unpublished observations). It is tempting to speculate that such changes could affect synaptic function and structure during development and in the mature brain, thus contributing to DS-related abnormalities.

In agreement with earlier observations, the current study raises the possibility that one or a few genes may make a conspicuous contribution to a neurobiological phenotype and in so doing direct studies to understand and treat these effects. But it also makes clear that for some phenotypes the contributions of more than one gene are biologically significant and additive. The data showing a significantly lessened severity in Ts1 Rhr of phenotypes present in Ts65Dn is evidence for this. It follows that to understand and treat these phenotypes it will be important to decipher the contributions to mechanism of several genes. The strategy pursued herein-i.e., the use of a series of well defined segmental trisomies to explore relevant and quantitatively defined phenotypes-has the potential to elucidate both simple and complex genetic contributions so that they may be targeted therapeutically. The Ts1Rhr mouse thus provides an important resource for such work. Future studies will benefit from the availability of this mouse and others created by chromosomal engineering to carry the genetic segment(s) and genes of interest.

\section{References}

Ahn KJ, Jeong HK, Choi HS, Ryoo SR, Kim YJ, Goo JS, Choi SY, Han JS, Ha I, Song WJ (2006) DYRK1A BAC transgenic mice show altered synaptic plasticity with learning and memory defects. Neurobiol Dis 22:463-472.

Aldridge K, Reeves RH, Olson LE, Richtsmeier JT (2007) Differential effects of trisomy on brain shape and volume in related aneuploid mouse models. Am J Med Genet A 143A:1060-1070.

Altafaj X, Dierssen M, Baamonde C, Martí E, Visa J, Guimerà J, Oset M, González JR, Flórez J, Fillat C, Estivill X (2001) Neurodevelopmental delay, motor abnormalities and cognitive deficits in transgenic mice overexpressing Dyrk1A (minibrain), a murine model of Down's syndrome. Hum Mol Genet 10:1915-1923.

Amano K, Sago H, Uchikawa C, Suzuki T, Kotliarova SE, Nukina N, Epstein CJ, Yamakawa K (2004) Dosage-dependent over-expression of genes in the trisomic region of Ts1Cje mouse model for Down syndrome. Hum Mol Genet 13:1333-1340.

Belichenko PV, Masliah E, Kleschevnikov AM, Villar AJ, Epstein CJ, Salehi A, Mobley WC (2004) Synaptic structural abnormalities in the Ts65Dn mouse model of Down Syndrome. J Comp Neurol 480:281-298.

Belichenko PV, Kleschevnikov AM, Salehi A, Epstein CJ, Mobley WC (2007) Synaptic and cognitive abnormalities in mouse models of Down syndrome: exploring genotype-phenotype relationships. J Comp Neurol 504:329-345.

Belichenko PV, Kleschevnikov AM, Masliah E, Wu C, Takimoto-Kimura R, Salehi A, Mobley WC (2009) Excitatory-inhibitory relationship in the fascia dentata in the Ts65Dn mouse model of Down syndrome. J Comp Neurol 512:453-466.

Bevins RA, Besheer J (2006) Object recognition in rats and mice: a one-trial non-matching-to-sample learning task to study 'recognition memory'. Nat Protoc 1:1306-1311.

Branchi I, Bichler Z, Minghetti L, Delabar JM, Malchiodi-Albedi F, Gonzalez MC, Chettouh Z, Nicolini A, Chabert C, Smith DJ, Rubin EM, MiglioreSamour D, Alleva E (2004) Transgenic mouse in vivo library of human
Down syndrome critical region 1: association between DYRK1A overexpression, brain development abnormalities, and cell cycle protein alteration. J Neuropathol Exp Neurol 63:429-440.

Brault V, Pereira P, Duchon A, Hérault Y (2006) Modeling chromosomes in mouse to explore the function of genes, genomic disorders, and chromosomal organization. PLoS Genet 2:e86.

Brown JH, Johnson MH, Paterson SJ, Gilmore R, Longhi E, Karmiloff-Smith A (2003) Spatial representation and attention in toddlers with Williams syndrome and Down syndrome. Neuropsychologia 41:1037-1046.

Canfield MA, Honein MA, Yuskiv N, Xing J, Mai CT, Collins JS, Devine O, Petrini J, Ramadhani TA, Hobbs CA, Kirby RS (2006) National estimates and race/ethnic-specific variation of selected birth defects in the United States, 1999-2001. Birth Defects Res A Clin Mol Teratol 76:747-756.

Costa AC, Grybko MJ (2005) Deficits in hippocampal CA1 LTP induced by TBS but not HFS in the Ts65Dn mouse: a model of Down syndrome. Neurosci Lett 382:317-322.

Deacon RM, Rawlins JN (2006) T-maze alternation in the rodent. Nat Protoc $1: 7-12$.

Delabar JM, Theophile D, Rahmani Z, Chettouh Z, Blouin JL, Prieur M, Noel B, Sinet PM (1993) Molecular mapping of twenty-four features of Down syndrome on chromosome 21. Eur J Hum Genet 1:114-124.

Demas GE, Nelson RJ, Krueger BK, Yarowsky PJ (1996) Spatial memory deficits in segmental trisomic Ts65Dn mice. Behav Brain Res 82:85-92.

Demas GE, Nelson RJ, Krueger BK, Yarowsky PJ (1998) Impaired spatial working and reference memory in segmental trisomy (Ts65Dn) mice. Behav Brain Res 90:199-201.

Escorihuela RM, Fernández-Teruel A, Vallina IF, Baamonde C, Lumbreras MA, Dierssen M, Tobeña A, Flórez J (1995) A behavioral assessment of Ts65Dn mice: a putative Down syndrome model. Neurosci Lett 199:143-146.

Escorihuela RM, Vallina IF, Martínez-Cué C, Baamonde C, Dierssen M, Tobeña A, Flórez J, Fernández-Teruel A (1998) Impaired short- and longterm memory in Ts65Dn mice, a model for Down syndrome. Neurosci Lett 247:171-174.

Fernandez F, Morishita W, Zuniga E, Nguyen J, Blank M, Malenka RC, Garner CC (2007) Pharmacotherapy for cognitive impairment in a mouse model of Down syndrome. Nat Neurosci 10:411-413.

Gardiner K, Fortna A, Bechtel L, Davisson MT (2003) Mouse models of Down syndrome: how useful can they be? Comparison of the gene content of human chromosome 21 with orthologous mouse genomic regions. Gene 318:137-147.

Gerlai R (2001) Behavioral tests of hippocampal function: simple paradigms complex problems. Behav Brain Res 125:269-277.

Granholm AC, Ford KA, Hyde LA, Bimonte HA, Hunter CL, Nelson M, Albeck D, Sanders LA, Mufson EJ, Crnic LS (2002) Estrogen restores cognition and cholinergic phenotype in an animal model of Down syndrome. Physiol Behav 77:371-385.

Holtzman DM, Santucci D, Kilbridge J, Chua-Couzens J, Fontana DJ, Daniels SE, Johnson RM, Chen K, Sun Y, Carlson E, Alleva E, Epstein CJ, Mobley WC (1996) Developmental abnormalities and age-related neurodegeneration in a mouse model of Down syndrome. Proc Natl Acad Sci U S A 93:13333-13338.

Hyde LA, Crnic LS (2001) Age-related deficits in context discrimination learning in Ts65Dn mice that model Down syndrome and Alzheimer's disease. Behav Neurosci 115:1239-1246.

Hyde LA, Crnic LS (2002) Reactivity to object and spatial novelty is normal in older Ts65Dn mice that model Down syndrome and Alzheimer's disease. Brain Res 945:26-30.

Kleschevnikov AM, Belichenko PV, Villar AJ, Epstein CJ, Malenka RC, Mobley WC (2004) Hippocampal long-term potentiation suppressed by increased inhibition in the Ts65Dn mouse, a genetic model of Down syndrome. J Neurosci 24:8153-8160.

Korenberg JR, Chen XN, Schipper R, Sun Z, Gonsky R, Gerwehr S, Carpenter N, Daumer C, Dignan P, Disteche C, et al (1994) Down syndrome phenotypes: the consequences of chromosomal imbalance. Proc Natl Acad Sci U S A 91:4997-5001.

Lyle R, Béna F, Gagos S, Gehrig C, Lopez G, Schinzel A, Lespinasse J, Bottani A, Dahoun S, Taine L, Doco-Fenzy M, Cornillet-Lefèbvre P, Pelet A, Lyonnet S, Toutain A, Colleaux L, Horst J, Kennerknecht I, Wakamatsu N, Descartes M, et al. (2008) Genotype-phenotype correlations in Down 
syndrome identified by array CGH in 30 cases of partial trisomy and partial monosomy chromosome 21. Eur J Hum Genet 17:454-466.

Mark MD, Herlitze S (2000) G-protein mediated gating of inward-rectifier K+ channels. Eur J Biochem 267:5830-5836.

Nelson L, Johnson JK, Freedman M, Lott I, Groot J, Chang M, Milgram NW, Head E (2005) Learning and memory as a function of age in Down syndrome: a study using animal-based tasks. Prog Neuropsychopharmacol Biol Psychiatry 29:443-453.

Nikolaienko O, Nguyen C, Crinc LS, Cios KJ, Gardiner K (2005) Human chromosome 21/Down syndrome gene function and pathway database. Gene 364:90-98.

Olson LE, Richtsmeier JT, Leszl J, Reeves RH (2004) A chromosome 21 critical region does not cause specific Down syndrome phenotypes. Science 306:687-690.

Olson LE, Roper RJ, Sengstaken CL, Peterson EA, Aquino V, Galdzicki Z, Siarey R, Pletnikov M, Moran TH, Reeves RH (2007) Trisomy for the Down syndrome 'critical region' is necessary but not sufficient for brain phenotypes of trisomic mice. Hum Mol Genet 16:774-782.

Pennington BF, Moon J, Edgin J, Stedron J, Nadel L (2003) The neuropsychology of Down syndrome: evidence for hippocampal dysfunction. Child Dev 74:75-93.

Pritchard MA, Kola I (1999) The "gene dosage effect" hypothesis versus the "amplified developmental instability" hypothesis in Down syndrome. J Neural Transm Suppl 57:293-303.

Rachidi M, Lopes C (2008) Mental retardation and associated neurological dysfunctions in Down syndrome: a consequence of dysregulation in critical chromosome 21 genes and associated molecular pathways. Eur J Paediatr Neurol 12:168-182.

Ramakrishna N, Meeker C, Li S, Jenkins EC, Currie JR, Flory M, Lee B, Liu MS, Miller DL (2005) Polymerase chain reaction method to identify Down syndrome model segmentally trisomic mice. Anal Biochem 340:213-219.

Reeves RH, Irving NG, Moran TH, Wohn A, Kitt C, Sisodia SS, Schmidt C, Bronson RT, Davisson MT (1995) A mouse model for Down syndrome exhibits learning and behaviour deficits. Nat Genet 11:177-184.
Reeves RH, Baxter LL, Richtsmeier JT (2001) Too much of a good thing: mechanisms of gene action in Down syndrome. Trends Genet 17:83-88.

Roizen NJ, Patterson D (2003) Down's syndrome. Lancet 361:1281-1289.

Roper RJ, Reeves RH (2006) Understanding the basis for Down syndrome phenotypes. PLoS Genet 2:e50.

Sago H, Carlson EJ, Smith DJ, Kilbridge J, Rubin EM, Mobley WC, Epstein CJ, Huang TT (1998) Ts1Cje, a partial trisomy 16 mouse model for Down syndrome, exhibits learning and behavioral abnormalities. Proc Natl Acad Sci U S A 95:6256-6261.

Sago H, Carlson EJ, Smith DJ, Rubin EM, Crnic LS, Huang TT, Epstein CJ (2000) Genetic dissection of region associated with behavioral abnormalities in mouse models for Down syndrome. Pediatr Res 48:606-613.

Saran NG, Pletcher MT, Natale JE, Cheng Y, Reeves RH (2003) Global disruption of the cerebellar transcriptome in a Down syndrome mouse model. Hum Mol Genet 12:2013-2019.

Siarey RJ, Stoll J, Rapoport SI, Galdzicki Z (1997) Altered long-term potentiation in the young and old Ts65Dn mouse, a model for Down Syndrome. Neuropharmacology 36:1549-1554.

Siarey RJ, Carlson EJ, Epstein CJ, Balbo A, Rapoport SI, Galdzicki Z (1999) Increased synaptic depression in the Ts65Dn mouse, a model for mental retardation in Down syndrome. Neuropharmacology 38:1917-1920.

Siarey RJ, Villar AJ, Epstein CJ, Galdzicki Z (2005) Abnormal synaptic plasticity in the Ts1Cje segmental trisomy 16 mouse model of Down syndrome. Neuropharmacology 49:122-128.

Silverman W (2007) Down syndrome: cognitive phenotype. Ment Retard Dev Disabil Res Rev 13:228-236.

Turner CA, Presti MF, Newman HA, Bugenhagen P, Crnic L, Lewis MH (2001) Spontaneous stereotypy in an animal model of Down syndrome: Ts65Dn mice. Behav Genet 31:393-400.

Uecker A, Obrzut JE (1993) Hemisphere and gender differences in mental rotation. Brain Cogn 22:42-50.

Yamada M, Inanobe A, Kurachi Y (1998) G protein regulation of potassium ion channels. Pharmacol Rev 50:723-760. 